\title{
PENERAPAN MODEL PEMBELAJARAN INTERAKTIF UNTUK MENINGKATKAN AKTIVITAS DAN HASIL BELAJAR IPA SISWA KELAS 5SD
}

\author{
Nugroho Widiantono, Nyoto Harjono \\ 292012228@student.uksw.edu, har.john59@gmail.com \\ PGSD, Universitas Kristen Satya Wacana \\ THE IMPLEMENTATION OF INTERACTIVE LEARNING MODEL \\ TO IMPROVE ACTIVITY AND LEARNING OUTCOME OF FIFTH GRADE STUDENTS \\ IN SCIENCE
}

\begin{abstract}
Based on science instructional observation activities especially KD 7.3 for fifth grade students of SDN Lanjan 02, the achievement score of teacher and student activity were low, similarly with the results of learning. This study aims to improve the activity and learning outcomes of science through the implementation of interactive learning model in fifth grade students of SDN Lanjan 02 in the second semester 2015/2016. The type of research is a collaborative type classroom action research conducted in two cycles, consisted of three meetings in each cycle. The instruments of the data collection are test and observation. The technique of data analysis is the comparative descriptive method by comparing learning activity, learning result, and mastery learning, that are taken from the result before the action and after the treatment is done, covering cycle I and cycle II. Based on the observation, the result of average score of individual student activity in pre cycle reached to $24.28 \%$ in $60.71 \%$ level. The score increased to $59.50 \%$ in cycle I and increased to $81.25 \%$ in cycle II. This means that the application of interactive learning model can improve student activity and learning outcomes in science learning.
\end{abstract}

Keywords: interactive learning, learning activity, science learning outcomes

$\begin{array}{ccc}\text { Article Info } & \text { Received date: } 29 \text { April } 2017 \quad \text { Revised date: } 23 \text { Mei } 2017 & \text { Accepted date: } 18 \text { September } 2017\end{array}$

\section{PENDAHULUAN}

Berdasarkan pengamatan terhadap kegiatan pembelajaran IPA siswa kelas 5 SDN Lanjan 02 semester II tahun pelajaran 2015/2016 ditemukan masalah dalam proses pembelajarannya. Pertama, ketika guru menyampaikan materi pelajaran sebagian siswa tidak memperhatikan, ada yang melamun, bercerita dengan teman, bermain sendiri, bahkan me(Rusman, Model-model Pembelajaran: Mengembangkan Profesionalisme Guru, 2010)(Rusmana, 2007)ngganggu teman lain. Artinya siswa kurang antusias mengikuti pembelajaran. Kedua, metode pembelajaran yang digunakan guru kurang melibatkan siswa untuk berpartisipasi aktif dan interaktif selama kegiatan pembelajaran, dan ketiga perolehan hasil belajar kurang maksimal.

Aktivitas belajar yang belum optimal dapat berdampak pada hasil belajar IPA yang cenderung rendah. Berdasarkandata nilai ulangan harian IPAkondisi awal, terdapat 13 dari 21 siswa belum mencapai Kriteria Ketuntasan Minimum (KKM) yang ditentukan oleh sekolah yaitu 71. Sedangkan yang telah mencapai KKM ( 271 ) hanya 8 siswa dengan persentase $38,10 \%$ dan yang belum mencapai KKM $(<71)$ sebesar 61,90\%.Selain itu nilai rata-rata kelas yang diperoleh masih 67,61. Artinya hasil belajar IPA belum maksimal dan cenderung rendah.

Dari masalah-masalah yang ditemukan, maka rumusan msalah yang diajukan adalah (1) Bagaimana penerapan model pembelajaran interaktif dapat meningkatkan aktivitas belajar IPA pada Kompetensi Dasar (KD) 7.4 mendeskripsikan proses daur air dan kegiatan manusia yang dapat mempengaruhinya dan KD 7.5 mendeskripsikan perlunya penghematan air pada siswa kelas 5 SDN Lanjan 02 semester II tahun pelajaran 2015/2016. (2) Apakah peningkatan aktivitas belajar melalui model pembelajaran interaktif dapat meningkatkan hasil belajar IPA pada KD 7.4 mendeskripsikan 
Penerapan Model Pembelajaran Interaktif untuk Meningkatkan Aktivitas dan Hasil Belajar IPA Siswa Kelas 5 SD (Nugroho Widiantono, Nyoto Harjono)

proses daur air dan kegiatan manusia yang dapat mempengaruhinya dan KD 7.5 mendeskripsikan perlunya penghematan air pada siswa kelas 5 SDN Lanjan 02 semester II tahun pelajaran 2015/2016.

Berdasarkan rumusan masalah yang diajukan, maka tujuan penelitian yang ingin dicapai yaitu (1) menerapkan model pembelajaran interaktif untuk meningkatkan aktivitas belajar siswa kelas 5 SDN Lanjan 02 pada pembelajaran IPA dengan KD 7.4 mendeskripsikan proses daur air dan kegiatan manusia yang mempengaruhinya dan KD 7.5 mendeskripsikan perlunya penghematan air, semester II tahun pelajaran 2015/2016. (2) meningkatkan hasil belajar IPA pada KD 7.4 mendeskripsikan proses daur air dan kegiatan manusia yang dapat mempengaruhinya dan KD 7.5 mendeskripsikan perlunya penghematan air pada siswa kelas 5 SDN Lanjan 02 semester II tahun pelajaran 2015/2016 melalui peningkatan aktivitas belajar dengan penerapan model pembelajaran interaktif.

\section{KAJIAN PUSTAKA \\ Pembelajaran IPA di SD}

Pembelajaran IPA sebaiknya dilakukan secara sistematis, hal tersebut untuk menumbuhkan kemampuan siswa dalam berpikir, bekerja dan bersikap secara ilmiah. Menurut Sulistyorini pembelajaran IPA di SD menekankan pada pemberian pengalaman belajar secara langsung melalui penggunaan dan pengembangan keterampilan proses dan sikap ilmiah(Sulistyorini, 2007). Sedangkan De Vito, et al. dalam (Samatowa, 2006) menegaskan bahwa "pembelajaran IPA yang baik harus mengaitkan IPA dengan kehidupan sehari-hari siswa. Siswa diberi kesempatan untuk mengajukan pertanyaan, mengembangkan ide-ide siswa, membangun rasa ingin tahu tentang segala sesuatu yang ada di lingkungannya, dan membangun keterampilan (skill) yang diperlukan untuk dipelajari."

\section{Aktivitas Belajar}

Pembelajaran merupakan hubungan antara proses dan hasil. Apabila proses belajar baik, maka dapat memberikan dampak baik pada hasil belajar. Dalam penelitian ini aktivitas belajar sebagai prosesnya, agar dapat memberi kontribusi terhadap hasil belajar IPA. Menurut Sardiman aktivitas belajar adalah aktivitas yang bersifat fisik maupun mental. Dalam proses belajar kedua aktivitas itu harus saling berkaitan(Sardiman, 2011).

Lebih lanjut Paul B. Diederich dalam (Hanafiah \& Suhana, 2010)menyatakan bahwa: "Aktivitas belajar terbagi dalam delapan kegiatan sebagai berikut: 1) Kegiatan-kegiatan visual (visual activities), yaitu membaca, melihat gambar-gambar, mengamati, eksperimen, demonstrasi, pemeran dan mengamati orang lain bekerja atau bermain. 2) Kegiatan-kegiatan lisan (oral activities), yaitu mengemukakan suatu fakta atau prinsip, menghubungkan suatu kejadian, mengajukan pertanyaan, memberi saran, mengemukakan pendapat, wawancara, diskusi dan interupsi. 3) Kegiatan-kegiatan mendengarkan (listening activities), yaitu mendengarkan penyajian bahan, mendengarkan percakapan dan diskusi kelompok, atau mendengarkan radio. 4) Kegiatan-kegiatan menulis (writing activities), yaitu menulis cerita, menulis laporan, memeriksa karangan, bahan-bahan copy, membuat outline atau rangkuman, dan mengerjakan tes serta mengisi angket. 5) Kegiatan-kegiatan menggambar (drawing activities), yaitu menggambar, membuat grafik, diagram, peta dan pola. 6) Kegiatan-kegiatan motorik (motor activities), yaitu melakukan percobaan, memilih alat-alat, melaksanakan pameran, membuat model, menyelenggarakan permainan, serta menari dann berkebun. 7) Kegiatan-kegiatan mental (mental activities), yaitu merenungkan, mengingat, memecahkan masalah, menganalisa faktor-faktor, melihat hubungan-hubungan, dan membuat keputusan. 8) Kegiatan-kegiatan emosional (emotional activities), yaitu minat, membedakan, berani, tenang, merasa bosan dan gugup."

Berdasarkan pendapat-pendapatyang telah dikemukakan, makaindikator pengamatan aktivitas siswadalam penelitian ini dapat mengacu pada delapan kegiatan aktivitas belajar menurut Diederich. Sedangkan yang dimaksud dengan aktivitas belajar dapat dipahami sebagaiaktivitas yang berkaitan dengan cara belajar, meliputi kegiatan fisik maupun mental yang saling berkaitan.

\section{Hasil Belajar}

Menurut Rusmanhasil belajar adalah sejumlah pengalaman yang siswa peroleh mencakup ranah kognitif, afektif, dan psikomotor(Rusman, Model-Model Pembelajaran: Mengembangkan Profesionalisme Guru, 2010). Lebih lanjut Sudjana menjelaskan bahwa: "hasil belajar meliputi tiga aspek, yaitu aspek kognitif, afektif, dan psikomotorik. Aspek kognitif berkenaan dengan hasil belajar intelektual yang terdiri dari enam aspek, yakni pengetahuan, ingatan, pemahaman, aplikasi, analisis, dan evaluasi. Aspek afektif berkenaan dengan sikap yang terdiri dari lima aspek, yakni penerimaan, 
jawaban atau reaksi, penilaian, organisasi, dan internalisasi. Aspek psikomotorik berkenaan dengan hasil belajar keterampilan dan kemampuan bertindak. Ada enam aspek ranah psikomotorik, yaitu gerakan refleks, keterampilan gerakan dasar, kemampuan perseptual, keharmonisan atau ketepatan, gerakan keterampilan kompleks, dan gerakan ekspresif atau interaktif."(Sudjana, 2012).

Berdasarkan paparan pendapat tersebut di atas, maka dalam penelitian ini hasil belajar dapat dilihat melalui kegiatan evaluasi yang bertujuan untuk mendapatkan data pembuktian yang akan menunjukan tingkat kemampuan siswa dalam mencapai tujuan pembelajaran yang mencakup ranah kognitif, afektif, dan psikomotor.

\section{Model Pembelajaran Interaktif}

Model pembelajaran interaktif "merupakan suatu pendekatan belajar yang merujuk pada pandangan konstruktivisme. Model belajar ini merupakan salah satu alternatif model pembelajaran yang dapat membantu siswa untuk berani mengungkapkan keingintahuannya dan ketidaktahuannya terhadap konsep yang sedang dipelajarinya"(Widodo, 2007). Sedangkan menurut Dasna pembelajaran interaktif mengacu pada interaksi antara peserta didik dengan pendidik, peserta didik dengan pengajar, atau juga peserta didik dengan media/sumber belajar(Dasna, 2015).

Menurut Faire \& Cosgrove dalam (Prayekti, 2004) model pembelajaran interaktif sering dikenal dengan nama pendekatan pertanyaan anak. Model ini dirancang agar siswa akan bertanya dan kemudian menemukan jawaban pertanyaan mereka sendiri. Berdasarkan pendapat yang telah dikemukakan, model pembelajaran interaktif dapat dipahami sebagai pembelajaran yang menekankan pada komunikasi antar siswa maupun siswa dengan guru melalui interaksi langsung dengan sumber belajar. Komunikasi dapat terjalin dari pemberian stimulus-stimulus untuk menggali pertanyaanpertanyaan siswa sebagai ungkapan rasa ingin tahu siswa terhadap pengetahuan yang akan dipelajari.

Model pembelajaran Interaktif lebih menekankan pertanyaan siswa sebagai ciri khasnya. Dalam model pembelajaran interaktif akan serig muncul pertanyaan-pertanyaan, dan pertanyaan dimungkinkan bervariasi. Menurut Louisel \& Descamps dalam (Majid, 2014) pertanyaan dalam proses pembelajaran memiliki tiga tujuan pokok, yakni meningkatkan tingkat berpikir siswa, mengecek pemahaman siswa, dan meningkatkan partisipasi belajar siswa.

Lebih lanjut Suparman dalam (Majid, 2014)menjelaskan bahwa "dalam pembelajaran interaktif terdapat tujuh karakteristik sebagai berikut, (1) adanya variasi kegiatan klasikal, kelompok, dan perseorangan, (2) keterlibatan mental (pikiran dan perasaan) siswa tinggi, (3) guru berperan sebagai fasilitator, narasumber, dan manajer kelas yang demokratis, (4) menerapkan pola komunikasi banyak arah, dan (5) suasana kelas yang fleksibel, demokratis, menantang, dan tetap terkendali oleh tujuan, (6) potensi dapat menghasilkan dampak pengiring lebih efektif, (7) dapat digunakan di dalam maupun di luar kelas." Suatu model pembelajaran dapat berhasil diterapkan dengan baik apabila dilaksanakan sesuai dengan langkah-langkah model pembelajaran tersebut. Menurut Emma Holmes (1995) dalam (Irsyadi, 2011) model pembelajaran interaktif dilaksanakan dalam lima langkah yang meliputi, (1) pengantar (introduction), (2) aktivitas atau pemecahan masalah (aktivity/problem solving), (3) fase saling membagi dan diskusi (sharing and discusing), (4) fase meringkas (summaring), (5) pelilaian unit belajar materi (assesment of learning of unit material).

Sedangkan menurut Faire \& Cosgrove (1988) dalam (Widodo, 2007), model pembelajaran interaktif terbagi dalam tujuh tahapan, yaitu: "Pertama adalahtahap persiapan, pada tahap ini guru dan siswa memilih serta mencari informasi tentang latar belakang topik, kemudian mengumpulkan sumber-sumber yang berkaitan dengan materi yang akan dipelajari. Kedua adalah tahap pengetahuan awal, dalam tahap ini siswa mencoba mengungkapkan pengetahuan awal mereka tentang topik yang akan dipelajari. Sementara guru berusaha menggali pengetahuan dasar siswa tentang topik yang akan dipelajari. Ketiga adalah tahap kegiatan eksplorasi, guru memberi penjelasan terkait topik yang ingin di eksplorasi. Dalam kegiatan eksplorasi siswa dilibatkan lebih mendalam terkait topik yang dipelajari. Dengan demikian siswa dirangsang untuk mengajukan pertanyaan. Keempat adalah tahap pertanyaan siswa, pada tahap ini seluruh siswa diajak untuk membuat pertanyaan mengenai topik yang dipelajari. Kelima adalah tahap penyelidikan, pada tahap ini guru dan siswa memilih pertanyaanpertanyaan yang akan dijawab melalui penyelidikan. Keenam adalah tahap pengetahuan akhir, pada tahap ini pengetahuan masing-masing siswa atau kelompok dikumpulkan dan dibandingkan dengan jawaban awal. Ketujuh adalah tahap refleksi, pada tahap ini diterapkan apa yang telah diuji atau dibuktikan dan apa yang masih perlu dimantapkan. Jika masih ditemukan pertanyaan susulan pada 
Penerapan Model Pembelajaran Interaktif untuk Meningkatkan Aktivitas dan Hasil Belajar IPA Siswa Kelas 5 SD (Nugroho Widiantono, Nyoto Harjono)

tahap refleksi ini dengan kata lain konsep belum terlalu dikuasai, maka perlu diulangi ke tahap penyelidikan."

Dari pendapat para ahli, penelitian ini mengacu pada langkah-langkah model pembelajaran interaktif menurut Holmes dengan rincian sebagai berikut:

Tabel 1. Langkah-langkah Model Pembelajaran Interaktif

\begin{tabular}{|c|c|c|}
\hline No. & Tahapan & Aktivitas \\
\hline 1. & Tahap pengantar & $\begin{array}{l}\text { Tahap mengorganisasikan kelas untuk belajar (kerja individual } \\
\text { atau kerja kelompok). Menentukan masalah atau aktivitas yang } \\
\text { akan diselidiki siswa berdasarkan pertanyaan-pertanyaan dari } \\
\text { siswa (pengetahuan awal). Menyampaikan tentang apa yang akan } \\
\text { siswa lakukan, misalnya menyelesaikan masalah, melakukan } \\
\text { aktivitas (penyelidikan, percobaan, pengamatan, atau berdiskusi), } \\
\text { melanjutkan atau mempelajari suatu topik, serta mengerjakan } \\
\text { tugas (proyek). }\end{array}$ \\
\hline 2. & $\begin{array}{l}\text { Tahap aktivitas } \\
\text { penyelesaian } \\
\text { masalah }\end{array}$ & $\begin{array}{l}\text { Tahap ini adalah inti model pembelajaran interaktif, melibatkan } \\
\text { siswa untuk berpikir dan merencanakan apa yang harus digali } \\
\text { dari materi pembelajaran, dan pembagian tugas (kelompok). } \\
\text { Guru mengamati, membimbing, dan memberi komentar terhadap } \\
\text { kegiatan siswa. Pada tahap ini akan terlihat situasi interaktif antar } \\
\text { siswa, antar siswa dalam kelompok, maupun antar siswa dengan } \\
\text { guru. }\end{array}$ \\
\hline 3. & $\begin{array}{l}\text { Tahap saling } \\
\text { berbagi dan diskusi }\end{array}$ & $\begin{array}{l}\text { Tahap siswa untuk melaporkan hasil penyelidikan atau } \\
\text { penyelesaian masalah dari pertanyaan mereka sendiri (individu) } \\
\text { atau kelompok, pelaporan dapat dilakukan melalui presentasi } \\
\text { atau diskusi saling bertukar pendapat untuk mendapatkan } \\
\text { kesimpulan. Sementara guru dapat memimpin, mengawasi, dan } \\
\text { memberi komentar dalam kegiatan diskusi atau presentasi } \\
\text { dengan menyampaiakan pertanyaan apa, mengapa, dan } \\
\text { bagaimana. Melalui pertanyaan itu memungkinkan melatih siswa } \\
\text { untuk berpikir tingkat tinggi dalam menghubungkan fakta-fakta } \\
\text { yang mereka temukan dari pengalaman dengan pengetahuan } \\
\text { awal mereka, menjadi konsep pengetahuan baru yang dipahami } \\
\text { siswa. }\end{array}$ \\
\hline 4. & Tahap meringkas & $\begin{array}{l}\text { Tahap siswa untuk memeriksa kembali apa yang telah dilakukan } \\
\text { atau dipelajari siswa. Kemudian membuat laporan hasil kegiatan } \\
\text { siswa berdasarkan pengalaman mereka dan apa yang telah } \\
\text { mereka pelajari secara ilmiah dengan bimbingan dari guru. }\end{array}$ \\
\hline 5. & $\begin{array}{l}\text { Tahap menilai } \\
\text { belajar }\end{array}$ & $\begin{array}{l}\text { Tahap melakukan penilaian belajar, siswa dan guru bersama- } \\
\text { sama menilai kegiatan pembelajaran dari awal sampai akhir } \\
\text { proses pembelajaran. Sehingga siswa diharapkan dapat } \\
\text { menguasai materi dengan baik. }\end{array}$ \\
\hline
\end{tabular}

Menurut Renny dalam(Majid, 2014) pembelajaran Interaktif memiliki enam kelebihan yaitu, (1) Siswa lebih banyak diberikan kesempatan untuk melibatkan keiingin tahuannya pada objek yang akan dipelajari. (2) Melatih mengungkapkan rasa ingin tahu melalui pertanyaan-pertanyaan yang diajukan oleh guru. (3) Memberikan sarana bermain bagi siswa melalui kegiatan eksplorasi dan investigasi. (4) Guru menjadi fasilitator, motivator, dan perancang aktivitas belajar. (5) Menempatkan siswa sebagai subjek pembelajara aktif. (5) Hasil belajar lebih bermakna.

Sedangkan kekurangan dari pembelajaran interaktif yakni, keberhasilan pembelajaran bergantung pada kemampuan dan kecakapan guru sebagai fasilitator dan manajer kelas dalam berkomunikasi multi arah untuk mengembangkan dinamika kelompok. Kekurangan tersebut dapat diatasi atau diminimalkandengan memberikan pengertian kepada guru tentang dinamika kelompok. Dinamika kelompok menurut Santosa (2004: 5) merupakan suatu kelompok yang teratur dari dua 
individu atau lebih yang mempunyai hubungan psikologis secara jelas antara anggota yang satu dengan yang lain, antar anggota kelompok mempunyai hubungan psikologis yang berlangsung dalam situasi yang dialami secara bersama-sama.

Terdapat 6 karakteristikk atau ciri suatu kelompok menurut Shaw (dalam Rusmana, 2007), yaitu (1) persepsi dan kognisi anggota kelompok, (2) motivasi dan kebutuhan kepuasan (need satisfication), (3) tujuan kelompok (Group Goals), (4) organisasi kelompok, (4) ada ketergantungan antara anggota kelompok, dan (6) interaksi. Dalam membentuk kelompok yang teratur dapat dilakukan dengan mengembangkan interaksi antar siswa melalui pembagian kerja/tugas, pengorganisasaian kelompok, membuat tujuan kelompok, dan kebersamaan kelompok.

Setelah mengkaji teori-teori yang relevan, selanjutnya mengakaji beberapa penelitian terdahulu yang relevan dengan penelitian ini. Menurut penelitian yang dilakukan oleh Pasri (Pasri, 2012) dengan judul "Upaya Penigkatan Hasil Belajar Siswa Tentang Penggolongan Hewan Berdasarkan Makanannya Melalui Penerapan Model Pembelajaran Interaktif di Kelas IV SD Karangwotan 03 Semester 1 Tahun 2011/2012" diperolehhasil penelitian bahwa penggunaan model pembelajaran interaktif dapat meningkatkan hasil belajar siswa. Pada siklus I nilai rata-rata kelompok sebesar 7,35 dengan persentase ketuntasan belajar siswa 65\%. Pada siklus II nilai rata-rata siswa kelompok 8,35 dengan persentase ketuntasan belajar siswa 90\%. Penerapan model pembelajaran interaktif terbukti dapat meningkatkan hasil belajar. Selanjutnya penelitian oleh Dwi Agung Susanto(Susanto, 2012) dengan judul "Peningkatan Motovasi Belajar IPA Melalui Model Pembelajaran Interaktif Pada Siswa Kelas IV Semester I SDN Wotan 02 Sukolilo Pati Tahun Pelajaran 2012/2013" diperoleh hasil penelitian bahwa terjadi peningkatan hasil belajar IPA. Pada siklus I persentase ketuntasan hasil belajar siswa sebesar $74 \%$ atau sebanyak 20 siswa dan pada siklus II meningkat menjadi $81 \%$ atau 22 siswa. Hal ini menjadi bukti bahwa dengan menerapkan model pembelajaran interaktif dapat meningkatkan hasil belajar siswa.

Kemudian penelitian oleh Bayu Widiyanto(Widiyanto, 2011) dengan judul "Penerapan Model Pembelajaran Interaktif Dengan Media Miniatur untuk Peningkatan Hasil belajar IPA pada Siswa Kelas III SDN Kemuning Lor 02 J ember" diperolehhasil penelitian bahwa terjadi peningkatan hasil belajar IPA. Dari hasil observasi untuk mengetahui hasil belajar siswa penilaian afektif, pada siklus I memperoleh persentase sebesar 73,3\%, kemudian pada siklus II meningkat menjadi 86,6\%. Dari hasil tersebut terjadi peningkatan hasil belajar siswa penilaian afektif sebesar 13,3\%. Untuk persentase hasil belajar siswa penilaian psikomotor, pada siklus I memperoleh persentase sebesar $70 \%$, sedangkan pada siklus II meningkat menjadi 83,3\%. Dari hasil tersebut terjadi peningkatan hasil belajar siswa penilaian psikomotor sebesar 13,3\%. Kemudian hasil belajar siswa penilaian kognitif siklus I memperoleh persentase sebesar 66,66\%, sedangkan pada siklus II meningkat menjadi 86,66\%. Berdasarkan hasil tersebut terjadi peningkatan persentase hasil belajar siswa penilaian kognitif sebesar 20\%. Kesimpulan dari penelitian Widiyanto (2011) yaitu penerapan model pembelajaran interaktif dengan media miniatur dapat meningkatkan hasil belajar IPA pada ranah afektif, kognitif dan psikomotor.

Persamaan penelitian ini dengan penelitian sebelumnya adalah sama-sama menerapkan model pembelajaran Interaktif. Sedangkan perbedaanya terdapat pada variabel terikatnya adalah aktivitas belajar dan hasil belajar, peneliti sebelumnya hanya sebatas hasil belajar saja. Kemudian subjek dalam penelitian ini adalah siswa kelas 5 SDN Lanjan 02. Selain itu yang menjadi latar belakang masalah dalam penelitian ini adalah aktivitas belajar yang belum optimal, yaitu siswa yang belum berpartisipasi aktif dalam pembelajaran. Sesuai tujuan penelitian ini, dengan menerapkan model pembelajaran interaktif pada pembelajaran IPA siswa kelas 5 SDN Lanjan 02 diharapkan dapat meningkatkan aktivitas belajar yang meliputi aktivitas guru dan aktivitas siswa. Aktivitas belajar yang menekankan pada interaksi dan komunikasi multi arah antara siswa dengan guru maupun dengan sumber belajar akan memberikan dampak yang berbeda dibandingkan aktivitas belajar yang belum melibatkan partisipasi aktif siswa. Dengan meningkatnya aktivitas belajar diharapkan dapat meningkatkan hasil belajar IPA secara signifikan, sehingga hasil belajar IPA lebih maksimal.

\section{Hipotesis Penelitian}

Berdasarkan pada landasan teori yang telah diuraikan maka hipotesis penelitian tindakan kelas ini sebagai berikut. (1) Penerapan model pembelajaran interaktif pada pembelajran IPA Kompetensi Dasar (KD) 7.4 mendeskripsikan proses daur air dan kegiatan manusia yang mempengaruhinya dan 
Penerapan Model Pembelajaran Interaktif untuk Meningkatkan Aktivitas dan Hasil Belajar IPA Siswa Kelas 5 SD (Nugroho Widiantono, Nyoto Harjono)

KD 7.5 mendeskripsikan perlunya penghematan air, diduga dapat meningkatkan aktivitas belajar siswa kelas 5 SDN Lanjan 02 semester II tahun pelajaran 2015/2016 secara signifikan minimal 15\% dengan langkah-langkah meliputi tahap pengantar, tahap aktivitas penyelesaian masalah, tahap saling berbagi dan diskusi, tahap meringkas, dan tahap menilai belajar. (2) Peningkatan aktivitas belajar melalui model pembelajaran interaktif diduga dapat meningkatkan hasil belajar IPA Kompetensi Dasar (KD) 7.4 mendeskripsikan proses daur air dan kegiatan manusia yang mempengaruhinya dan KD 7.5 mendeskripsikan perlunya penghematan air pada siswa kelas 5 SDN Lanjan 02 semester II tahun pelajaran 2015/2016 secara signifikan mengalami peningkatan ketuntasan belajar secara klasikal dengan nilai rata-rata hasil belajar IPA meningkat minimal 10 poin dari nilai KKM $(\geq 71)$ yang telah ditentukan atau ketuntasan belajar klasikal sebesar 85\% dari 21 siswa (dengan kategori sangat tinggi).

\section{METODE PENELITIAN \\ Setting Tempat Penelitian}

Tempat penelitian ini di SD Negeri Lanjan 02 Kecamatan Sumowono Kabupaten Semarang. Lokasi SD Negeri Lanjan 02 strategis karena terletak di tepi jalan dan dikelilingi pemukiman warga. Tempat yang strategis membuat siswa mudah untuk menjangkaunya. Selain mudah dijangkau dari rumah siswa, kondisi tempat tersebut menciptakan lingkungan belajar yang kondusif dalam mendukung setiap kegiatan belajar mengajar. Penelitian ini dilakukan pada semester genap tahun pelajaran 2015/2016 di SD Negeri Lanjan 02. Penentuan waktu penelitian dilakukan kesepakatan antara peneliti, guru kolaboratif, dan kepala sekolah untuk menyesuaikan agenda sekolah tersebut yang mengacu pada kalender akademik sekolah. Penelitian ini dilakukan kurang lebih selama 4 bulan yaitu bulan Februari - Mei 2016.

\section{Karakteristik Subjek Penelitian}

Subjek yang akan diteliti adalah siswa kelas 5 SD Negeri Lanjan 02 Kecamatan Sumowono Kabupaten Semarang tahun pelajaran 2015/2016 yang terdiri dari 21 siswa, dengan siswa laki-laki sebanyak 7 siswa dan 14 siswa perempuan yang memiliki karakteristik heterogen. enis penelitian yang dilakukan adalah Penelitian Tindakan Kelas (PTK). Menurut Arikunto PTK adalah penelitian tindakan (JAction research) yang dilakukan sebagai upaya untuk memperbaiki tindakan pembelajaran yang dilakukan oleh guru di kelas sehingga diharapkan dapat meningkatkan mutu pembelajaran (Arikunto, 2010). Penelitian ini dilaksanakan dalam dua siklus dengan menggunakan model spiral dari Stephen Kemmis \& Robin McTaggart. Menurut Kemmis \& McTaggart dalam (Arikunto, 2012) prosedur penelitian tindakan mencakup tiga langkah yaitu, perencanaan tindakan (planning), pelaksanaan tindakan (acting) dan observasi (observation), sertarefleksi (reflecting).

\section{Rencana Pelaksanaan Tindakan}

Penelitian ini dilakukan dalam dua siklus dengan tiap siklus dilaksanakan tiga kali pertemuan yang terdiri dari dua pertemuan tatap muka dan satu pertemuan evaluasi. Siklus I terdiri tari tiga tahap meliputi, tahap perencanaan tindakan, pelaksanan tindakan dan observasi, serta refleksi. Hasil refleksi pada siklus I digunakan untuk perbaikan pada pembelajaran siklus II. Tahapan pada siklus II meliputi, tahap perencanaan tindakan, tahap pelaksanaan tindakan dan observasi, serta refleksi. Apabila pembelajaran pada siklus II sudah memenuhi pencapaian untuk aktivitas belajar meningkat secara signifikan minimal 15\%, dan ketuntasan belajar secara klasikal dengan nilai rata-rata hasil belajar IPA meningkat minimal 10 skor dari nilai KKM $(\geq 71)$ yang telah ditentukan atau ketuntasan belajar klasikal sebesar $85 \%$ dari 21 siswa. Maka tidak perlu diadakan perbaikan kembali dan penerapan model pembelajaran interaktif pada pembelajaran IPA dinyatakan berhasil.

\section{Teknik Pengumpulan Data}

Menurut Sudjana, "tes sebagai penilaian adalah pertanyaan-pertanyaan yang diberikan kepada siswa untuk mendapat jawaban dari siswa dalam bentuk lisan (tes lisan, atau dalam bentuk perbuatan (tes tindakan). Pada umumnya tes digunakan untuk menilai dan mengukur hasil belajar siswa, terutama hasil belajar kognitif berkenaan dengan penguasaan bahan pengajaran sesuai dengan tujuan pendidikan dan pengajaran" (Sudjana, 2012). Dalam penelitian ini tes digunakan untuk mengukur besarnya kemampuan subjek penelitian serta mengetahui besarnya kemajuan hasil belajar setelah mencapai tujuan pembelajaran pada 
setiap akhir siklus. Alat yang digunakan untuk mengumpulkan data adalah tes penilaian tertulis (pilihan ganda). Menurut Hadi dalam (Sugiyono, 2013) observasi merupakan suatu proses yang kompleks, suatu proses yang tersusun dari berbagai proses biologis dan psikologis. Dalam penelitian ini observasi digunakan untuk mengetahui kemajuan aktivitas siswa dan guru selama proses pembelajaran. Sedangkan observasi dilakukan oleh observer.

Menurut Sugiyono (Sugiyono, 2013) dokumentasi merupakan catatan peristiwa yang sudah berlalu. Dokumentasi bisa berbentuk tulisan, gambar, atau karya-karya menumental seseorang. Penelitian ini menggunakan dokumentasi sebagai bukti nyata penelitian yang telah dilaksanakan. Selain itu dokumntasi dapat memperkuat data yang diperoleh dari observasi.

Data yang diperoleh dari hasil pelaksanaan penelitian tindakan kelas adalah data kuantititatif. Menurut Slameto yang dimaksud data kuantitatif, adalah data yang dinyatakan dalam angka(Slameto, 2015). Penelitian ini menggunakan analisis kuantitatif dengan statistik deskriptif. Sedangkan data hasil belajar IPA dianalisis menggunakan teknik analisis deskriptif komparatif untuk membandingkan hasil belajar setelah tindakan siklus I dan siklus II.

\section{HASIL PENELITIAN DAN PEMBAHASAN \\ Deskripsi Prasiklus}

Berdasarkan pengamatan terhadap proses belajar mengajar IPA siswa kelas 5 SDN Lanjan 02 sebelum dilaksanakan tindakan menunjukan adanya permasalahan. Proses pembelajaran IPA masih berpusat pada guru, akibatnya siswa menjadi pasif dan kurang antusias mengikuti pembelajaran.Terbukti dari hasil observasi aktivitas guru prasiklus, dari 25 indikator pengamatan memperoleh skor 45 dengan persentasae $45 \%$ masuk dalam kategori rendah. Kemudian aktivitas siswa prasiklus memperoleh rata-rata skor klasikal sebesar 24,28 dengan persentase $60,7 \%$ masuk dalam kategori cukup.

Ternyata aktivitas belajar yang belum optimal berdampak pada rendahnya hasil belajar. Hasil tes ulangan harian IPA menunjukan nilai rata-rata klasikal 67,61 yang berarti belum mencapai KKM (71). Nilai tertinggi yang diperoleh siswa adalah 80 sedangkan nilai terendahnya 50. Kemudian ketuntasan belajar prasiklus sebanyak 13 siswa dinyatakan belum mencapai KKM atau 61,90\% dari keseluruhan siswa, sedangkan yang dinyatakan tuntas sebanyak 8 siswa atau 38,10\% dari keseluruhan siswa.

\section{Deskripsi Siklus I}

Dalam pelaksanaan tindakan pada siklus I meliputi tahap perencanaan tindakan, pelaksanaan tindakan dan observasi, serta refleksi. Pada tahap perencanaan tindakan penulis bersama guru kolabolator menyusun RPP pembelajaran IPA pokok bahasan penghematan air berdasarkan sintaks model pembelajaran interaktif, menyiapkan alat dan media pembelajaran, serta instrumen tes evaluasi, lembar kerja siswa dan lembar kerja kelompok. Tahap pelaksanaan tindakan guru kolabolator melaksanakan tindakan pembelajaran IPA pokok bahasan daur air menggunakan model pembelajaran interaktif yang telah disusun pada tahap sebelumnya. Pada tahap observasi dilakukan oleh observer untuk mengamati aktivitas belajar meliputi aktivitas guru, aktivitas individu siswa, aktivitas kelompok sisiwa selama kegiatan pembelajaran IPA menggunakan model pembelajaran interaktif. Kemudian setelah tindakan pembelajaran terlaksana secara keseluruhan dilakukan refleksi sebagai bahan perbaikan dengan membandingkan hasil tindakan selama proses pembelajaran dengan indikator yang diharapkan.

Berdasarkan pengamatan terhadap proses pembelajaran IPA menggunakan model pembelajaran interaktif pada siswa kelas 5 SDN Lanjan 02 diperoleh data aktivitas belajar siklus I. Aktivitas belajar meliputi aktivitas guru, aktivitas individu siswa, dan aktivitas kelompok siswa. Aktivitas guru adalah pelaksanaan sintaks model pembelajaran interaktif oleh guru dalam pembelajaran IPA yang terdiri dari 25 indikator, setiap indikator terdiri dari 4 deskriptor pengamatan dengan rentang skor penilaian $1-4$ disajikan pada tabel 2 sebagai berikut. 
Penerapan Model Pembelajaran Interaktif untuk Meningkatkan Aktivitas dan Hasil Belajar IPA Siswa Kelas 5 SD (Nugroho Widiantono, Nyoto Harjono)

Tabel 2. Hasil Observasi Aktivitas Guru Siklus I

\begin{tabular}{|c|c|c|c|c|}
\hline \multirow{2}{*}{ No } & \multirow{2}{*}{ Aspek yang Diamati } & \multirow{2}{*}{ Indikator } & \multicolumn{2}{|c|}{ Skor } \\
\hline & & & Pertemuan 1 & Pertemuan 2 \\
\hline 1. & $\begin{array}{l}\text { Melakukan apersepsi, motivasi, dan } \\
\text { menyampaikan kompetensi yang akan } \\
\text { dicapai. }\end{array}$ & $1-4$ & 9 & 14 \\
\hline 2. & Pengantar & $5-11$ & 16 & 19 \\
\hline 3. & Aktivitas penyelesaian masalah & $12-14$ & 7 & 8 \\
\hline 4. & Saling berbagi dan diskusi & $15-17$ & 8 & 9 \\
\hline 5. & Meringkas & 18,19 & 6 & 6 \\
\hline 6. & Menilai belajar & 20,21 & 4 & 5 \\
\hline 7. & Penutup & $22-25$ & 11 & 12 \\
\hline \multicolumn{3}{|c|}{ Total Skor } & 61 & 73 \\
\hline \multicolumn{3}{|c|}{ Kriteria } & Cukup & Tinggi \\
\hline & Rata-rata skor siklus I & & \multicolumn{2}{|c|}{67} \\
\hline
\end{tabular}

Berdasarkan data tabel2, dapat dilihat aktivitas guru pada pertemuan pertama dan kedua siklus I mengalami peningkatan.Pada pertemuan pertama memperoleh skor 61 dengan kriteria cukup meningkat menjadi 73 dengan kriteria tinggi pada pertemuan kedua. Sehingga diperoleh rata-rata skor aktivitas guru siklus I sebesar 67.

Kemudian aktivitas siswa yang meliputi aktivitas individu dan kelompok siswa,yaitu kegiatan-kegiatan atau aktivitas-aktivitas yang dilakukan siswa selama pembelajaran IPA.Observasi dilakukan menggunakan aspek pengamatan aktivitas menurut Diederich yang terdiri dari 10 indikator, setiap indikator terdiri dari 4 deskriptor pengamatan dengan rentang skor penilaian $1-4$. Berdasarkan hasil observasi terhadap aktivitas individu siswa siklus I, diperoleh data hasil observasi yang disajikan dalam tabel 3 sebagai berikut.

Tabel 3.Hasil Observasi Aktivitas Individu Siswa Siklus I

\begin{tabular}{|c|c|c|c|}
\hline \multirow{2}{*}{ No } & \multirow{2}{*}{ Aktivitas yang diamati } & \multicolumn{2}{|c|}{ Skor klasikal } \\
\hline & & Pertemuan 1 & Pertemuan 2 \\
\hline 1. & Kegiatan lisan & 59 & 62 \\
\hline 2. & Kegiatan visual & 57 & 66 \\
\hline 3. & Kegiatan mendengarkan & 52 & 61 \\
\hline 4. & Kegiatan menulis & 51 & 56 \\
\hline 5. & Kegiatan metrik & 53 & 63 \\
\hline 6. & Kegiatan mental & 57 & 58 \\
\hline 7. & Kegiatan emosional & 56 & 66 \\
\hline 8. & Kegiatan menggambar & 58 & 58 \\
\hline 9. & Kegiatan menyimpulkan & 55 & 64 \\
\hline 10. & Antusiasme siswa dalam pembelajaran & 48 & 63 \\
\hline & Total skor & 546 & 617 \\
\hline & Rata-rata klasikal & 26 & 29,38 \\
\hline & Kriteria & Cukup & Tinggi \\
\hline & Rata-rata skor siklus I & \multicolumn{2}{|c|}{27,69} \\
\hline
\end{tabular}

Berdasarkan data tabel 3, dapat dilihat terjadi peningkatan aktivitas individu siswa pada pertemuan pertama dan kedua siklus I.Pada pertemuan pertama diperoleh rata-rata klasikal 21 siswa sebesar 26 dengan kriteria cukup, meningkat menjadi 29,38 pada pertemuan kedua. Sehingga diperoleh rata-rata skor siklus I sebesar 27,69. Kemudian data hasil observasi terhadap aktivitas kelompok siswa pada siklus I disajikan dalam tabel 4 sebagai berikut. 
Tabel 4. Hasil Observasi Aktivitas Kelompok Siswa Siklus I

\begin{tabular}{|c|c|c|c|}
\hline \multirow{2}{*}{ No } & \multirow{2}{*}{ Aktivitas yang diamati } & \multicolumn{2}{|c|}{ Skor rata-rata klasikal } \\
\hline & & Pertemuan 1 & Pertemuan 2 \\
\hline 1. & Kegiatan lisan & 10 & 14 \\
\hline 2. & Kegiatan visual & 12 & 13 \\
\hline 3. & Kegiatan mendengarkan & 12 & 13 \\
\hline 4. & Kegiatan menulis & 10 & 12 \\
\hline 5. & Kegiatan metrik & 13 & 13 \\
\hline 6. & Kegiatan mental & 14 & 14 \\
\hline 7. & Kegiatan emosional & 12 & 13 \\
\hline 8. & Kegiatan menggambar & 10 & 14 \\
\hline 9. & Kerjasama kelompok & 10 & 12 \\
\hline 10. & Kontribusi siswa dalam kelompok & 7 & 10 \\
\hline & Total skor & 110 & 128 \\
\hline & Rata-rata kelompok & 22 & 25,60 \\
\hline & Kriteria & Cukup & Cukup \\
\hline & Rata-rata skor siklus I & \multicolumn{2}{|c|}{23,80} \\
\hline
\end{tabular}

Berdasarkan data tabel 4, dapat dilihat terjadi peningkatan aktivitas kelompok siswa pada pertemuan pertama dan kedua siklus I. Pada pertemuan pertama diperoleh rata-rata skor 5 kelompok sebesar 22 dengan kriteria cukup, meningkat menjadi 25,60 dengan kriteria cukup pada pertemuan kedua. Sehingga diperoleh rata-rata skor siklus I sebesar 23,80.

Selanjutnya data hasil belajar IPA siklus I pada siswa kelas 5 SDN Lanjan 02 diperoleh setelah dilaksanakannya tes evaluasi di akhir siklus I.Nilai rata-rata kelas 75 dengan nilai tertinggi 80, sedangkan nilai terendah 60 . Ketuntasan belajar siklus I diperoleh data sebanyak 15 siswa atau $71,20 \%$ dari keseluruhan siswa telah tuntas mencapai KKM (71), sedangkan yang belum tuntas sebanyak 6 siswa atau 28,60\% dari keseluruhan siswa. Artinya hasil belajar IPA siklus I belum memenuhi indikator hasil pencapaian $85 \%$ dari 21 siswa tuntas, maka perlu dilakukan tindak lanjut pada siklus II.

\section{Deskripsi Siklus II}

Dalam pelaksanaan tindakan pada siklus I meliputi tahap perencanaan tindakan, pelaksanaan tindakan dan observasi, serta refleksi. Pada tahap perencanaan tindakan penulis bersama guru kolabolator menyusun RPP pembelajaran IPA pokok bahasan penghematan air berdasarkan sintaks model pembelajaran interaktif, menyiapkan alat dan media pembelajaran, serta instrumen tes evaluasi, lembar kerja siswa dan lembar kerja kelompok. Tahap pelaksanaan tindakan guru kolabolator melaksanakan tindakan pembelajaran IPA pokok bahasan daur air menggunakan model pembelajaran interaktif yang telah disusun pada tahap sebelumnya. Pada tahap observasi dilakukan oleh observer untuk mengamati aktivitas belajar meliputi aktivitas guru, aktivitas individu siswa, aktivitas kelompok sisiwa selama proses pembelajaran IPA menggunakan model pembelajaran interaktif. Kemudian setelah tindakan pembelajaran terlaksana secara keseluruhan dilakukan refleksi sebagai bahan perbaikan dengan membandingkan hasil tindakan selama proses pembelajaran dengan indikator yang diharapkan.

Berdasarkan pengamatan terhadap proses pembelajaran IPA menggunakan model pembelajaran interaktif pada siswa kelas 5 SDN Lanjan 02 diperoleh data aktivitas belajar siklus II. Aktivitas belajar meliputi aktivitas guru, aktivitas individu siswa, dan aktivitas kelompok siswa. Aktivitas guru adalah pelaksanaan sintaks model pembelajaran interaktif oleh guru dalam pembelajaran IPA yang terdiri dari 25 indikator, setiap indikator terdiri dari 4 deskriptor pengamatan dengan rentang skor penilaian $1-4$ disajikan pada tabel 5 sebagai berikut. 
Penerapan Model Pembelajaran Interaktif untuk Meningkatkan Aktivitas dan Hasil Belajar IPA Siswa Kelas 5 SD (Nugroho Widiantono, Nyoto Harjono)

Tabel 5. Hasil Observasi Aktivitas Guru Siklus II

\begin{tabular}{|c|c|c|c|c|}
\hline \multirow[b]{2}{*}{ No } & \multirow[b]{2}{*}{ Aspek yang Diamati } & \multirow[b]{2}{*}{ Indikator } & \multicolumn{2}{|c|}{ Skor } \\
\hline & & & Pertemuan 1 & Pertemuan 2 \\
\hline 1. & $\begin{array}{l}\text { Melakukan apersepsi, motivasi, dan } \\
\text { menyampaikan kompetensi yang } \\
\text { akan dicapai. }\end{array}$ & $1-4$ & 14 & 14 \\
\hline 2. & Pengantar & $5-11$ & 24 & 27 \\
\hline 3. & Aktivitas penyelesaian masalah & $12-14$ & 10 & 11 \\
\hline 4. & Saling berbagi dan diskusi & $15-17$ & 11 & 12 \\
\hline 5. & Meringkas & 18,19 & 6 & 7 \\
\hline 6. & Menilai belajar & 20,21 & 6 & 6 \\
\hline 7. & Penutup & $22-25$ & 13 & 13 \\
\hline \multicolumn{3}{|c|}{ Total Skor } & 84 & 90 \\
\hline \multicolumn{3}{|c|}{ Kriteria } & Tinggi & Sangat Tinggi \\
\hline & Rata-rata skor siklus II & & \multicolumn{2}{|r|}{87} \\
\hline
\end{tabular}

Berdasarkan data tabel 5, dapat dilihat aktivitas guru pada pertemuan pertama dan kedua siklus II mengalami peningkatan. Pada pertemuan pertama memperoleh skor 84 dengan kriteria tinggi meningkat menjadi 90 dengan kriteria sangat tinggi pada pertemuan kedua. Sehingga diperoleh ratarata skor aktivitas guru siklus II sebesar 87.

Kemudian aktivitas siswa yang meliputiaktivitas individu dan kelompok siswa, yaitu kegiatan-kegiatan atau aktivitas-aktivitas yang dilakukan siswa selama pembelajaran IPA. Observasi dilakukan menggunakan aspek pengamatan aktivitas menurut Diederich yang terdiri dari 10 indikator, setiap indikator terdiri dari 4 deskriptor pengamatan dengan rentang skor $1-4$. Berdasarkan hasil observasi terhadap aktivitas individu dan kelompok siswa siklus II, diperoleh data rata-rata skor klasikal yang disajikan dalam tabel 6 sebagai berikut.

Tabel 6.Hasil Observasi Aktivitas Individu Siswa Siklus II

\begin{tabular}{|c|c|c|c|}
\hline \multirow{2}{*}{ No } & \multirow{2}{*}{ Aktivitas yang diamati } & \multicolumn{2}{|c|}{ Skor klasikal } \\
\hline & & Pertemuan 1 & Pertemuan 2 \\
\hline 1. & Kegiatan lisan & 71 & 78 \\
\hline 2. & Kegiatan visual & 73 & 74 \\
\hline 3. & Kegiatan mendengarkan & 73 & 75 \\
\hline 4. & Kegiatan menulis & 67 & 73 \\
\hline 5. & Kegiatan metrik & 68 & 69 \\
\hline 6. & Kegiatan mental & 74 & 78 \\
\hline 7. & Kegiatan emosional & 66 & 68 \\
\hline 8. & Kegiatan menggambar & 71 & 74 \\
\hline 9. & Kegiatan menyimpulkan & 64 & 73 \\
\hline & Antusiasme siswa dalam pembelajaran & 68 & 73 \\
\hline & Total skor & 695 & 735 \\
\hline & Rata-rata klasikal & 33,10 & 35 \\
\hline & Kriteria & Tinggi & Tinggi \\
\hline & Rata-rata skor siklus II & \multicolumn{2}{|c|}{34,05} \\
\hline
\end{tabular}

Berdasarkan data tabel 6 , dapat dilihat terjadi peningkatan aktivitas individu siswa pada pertemuan pertama dan kedua siklus II. Pada pertemuan pertama diperoleh rata-rata klasikal 21 siswa sebesar 33,10 dengan kriteria tinggi, meningkat menjadi 35 pada pertemuan kedua dengan kriteria tinggi. Sehingga diperoleh rata-rata skor siklus II sebesar 34,05. Kemudian data hasil observasi terhadap aktivitas kelompok siswa pada siklus II disajikan dalam tabel 7 sebagai berikut. 
Tabel 7. Hasil Observasi Aktivitas Kelompok Siswa Siklus II

\begin{tabular}{clcc}
\hline \multirow{2}{*}{ No } & \multicolumn{2}{c}{ Aktivitas yang diamati } & \multicolumn{2}{c}{ Skor rata-rata klasikal } \\
\cline { 3 - 4 } & \multicolumn{1}{c}{ Kegiatan lisan } & Pertemuan 1 & Pertemuan 2 \\
\hline 1. & Kegiatan visual & 14 & 19 \\
\hline 3. & Kegiatan mendengarkan & 15 & 18 \\
\hline 4. & Kegiatan menulis & 17 & 18 \\
\hline 5. & Kegiatan metrik & 15 & 16 \\
\hline 6. & Kegiatan mental & 15 & 18 \\
\hline 7. & Kegiatan emosional & 14 & 17 \\
\hline 8. & Kegiatan menggambar & 15 & 17 \\
\hline 9. & Kerjasama kelompok & 17 & 17 \\
\hline 10. & Kontribusi siswa dalam kelompok & 15 & 173 \\
\hline \multicolumn{2}{r}{ Total skor } & 152 & 34,60 \\
\hline \multicolumn{2}{c}{ Rata-rata kelompok } & 30,40 & Tinggi \\
\hline \multicolumn{2}{c}{ Kriteria } & Tinggi & 32,50 \\
\hline
\end{tabular}

Berdasarkan data tabel 7, dapat dilihat terjadi peningkatan aktivitas kelompok siswa pada pertemuan pertama dan kedua siklus II. Pada pertemuan pertama diperoleh rata-rata skor 5 kelompok sebesar 30,40 dengan kriteria tinggi, meningkat menjadi 34,60 dengan kriteria tinggi pada pertemuan kedua. Sehingga diperoleh rata-rata skor siklus I sebesar 32,50.

Selanjutnya data hasil belajar IPA siklus II diperoleh setelah dilaksanakannya tes evaluasi di akhir siklus. Berdasarkan data hasil evaluasi diperoleh nilai rata-rata kelas 85, dengan nilai tertinggi 100, sedangkan nilai terendah 75. Pada ketuntasan belajar siklus II diperoleh data sebanyak 21 siswa atau $100 \%$ telah tuntas mencapai KKM (71). Artinya hasil belajar IPA siklus II telah memenuhi indikator hasil pencapaian sebanyak $85 \%$ dari 21 siswa tuntas, sehingga penerapan model pembelajaran interaktif dalam pembelajaran IPA pada kelas 5 SDN Lanjan 02 dinyatakan berhasil meningkatkan aktivitas dan hasil belajar.

\section{Analisis Komparatif}

\section{a) Aktivitas Belajar}

Setelah dilakukan pengamatan terhadap proses pembelajaran IPA dari prasiklus, siklus I, dan siklus II telah diperoleh data perbandingan hasil observasi aktivitas belajar yang disajikan dalam tabel 8 sebagai berikut.

Tabel 8.

Perbandingan Hasil Observasi Aktivitas BelajarPrasiklus, Siklus I, dan Siklus II

\begin{tabular}{clcccccc}
\hline \multirow{2}{*}{ No } & \multirow{2}{*}{ Tindakan } & \multicolumn{2}{c}{ Prasiklus } & \multicolumn{2}{c}{ Siklus I } & \multicolumn{2}{c}{ Siklus II } \\
\cline { 3 - 8 } & & Skor & $\%$ & $\bar{x}$ & $\%$ & $\bar{x}$ & $\%$ \\
\hline 1. & Aktivitas Guru & 45 & 45 & 67 & 67 & 87 & 87 \\
\hline 2. & Aktivitas Individu Siswa & 24,28 & 60,71 & 27,69 & 69,23 & 34,05 & 85,11 \\
\hline 3. & Aktivitas Kelompok Siswa & - & - & 23,80 & 59,50 & 32,50 & 81,25 \\
\hline
\end{tabular}

Berdasarkan tabel 8, dapat diketahui bahwa terjadi peningkatan aktivitas guru, aktivitas individu siswa, dan aktivitas kelompok siswa dari prasiklus, siklus I, dan siklus II. Pada prasiklus total skor aktivitas guru 45 atau $45 \%$, setelah penerapan model pembelajaran interaktif pada siklus I terjadi peningkatan skor menjadi 67 atau 67\%, dan pada siklus II meningkat menjadi 87 atau 87\%. Rata-rata skor aktivitas siswa juga mengalami peningkatan, pada prasiklus rata-rata skor aktivitas individu siswa 24,28 atau 60,71\%, kemudian meningkat pada siklus I menjadi 27,69 atau 69,23\%, dan pada siklus II meningkat menjadi 34,05 atau $85,11 \%$. Untuk aktivitas kelompok siswa pada prasiklus belum terdapat aktivitas kelompok, pada siklus I rata-rata skor aktivitas kelompok siswa mengalami 
Penerapan Model Pembelajaran Interaktif untuk Meningkatkan Aktivitas dan Hasil Belajar IPA Siswa Kelas 5 SD (Nugroho Widiantono, Nyoto Harjono)

peningkatan menjadi 23,80 atau $59,50 \%$, dan pada siklus II rata-rata skor meningkat menjadi 32,50atau 81,25\%.

\section{b) Hasil Belajar}

Hasil belajar diperoleh dari tes evaluasi yang dilakukan pada setiap akhir siklus. Dari prasiklus, siklus I, dan siklus II telah terjadi peningkatan nilai rata-rata kelas dan ketuntasan belajar pada pembelajaran IPA. Adapun data perbandingannya dasajikandalam tabel 9 sebagai berikut.

Tabel 9.

PerbandinganKetuntasan dan Hasil Belajar IPAPrasiklus, Siklus I, Siklus II

\begin{tabular}{|c|c|c|c|c|c|c|c|c|}
\hline \multirow{2}{*}{ No } & \multirow{2}{*}{$\begin{array}{c}\text { Ketuntasan } \\
\text { Belajar }\end{array}$} & \multirow{2}{*}{ Nilai } & \multicolumn{2}{|c|}{ Prasiklus } & \multicolumn{2}{|c|}{ Siklus I } & \multicolumn{2}{|c|}{ Siklus II } \\
\hline & & & Jumlah & $\%$ & Jumlah & $\%$ & Jumlah & $\%$ \\
\hline 1 & Tuntas & $\geq 71$ & 8 & $38,10 \%$ & 15 & $71,40 \%$ & 21 & $100 \%$ \\
\hline 2 & Belum Tuntas & $<71$ & 13 & $61,90 \%$ & 6 & $28,60 \%$ & 0 & $0 \%$ \\
\hline \multicolumn{3}{|c|}{ Total } & 21 & $100 \%$ & 21 & $100 \%$ & 21 & $100 \%$ \\
\hline \multicolumn{3}{|c|}{ Nilai Rata-Rata Kelas } & \multicolumn{2}{|c|}{67,61} & \multicolumn{2}{|c|}{75} & \multicolumn{2}{|c|}{85} \\
\hline
\end{tabular}

Berdasarkan data pada tabel 9, dapat diketahui bahwa pada prasiklus siswa yang tuntas (KKM 271) berjumlah 8 siswa atau 38,10\%, sedangkan siswa yang belum tuntas 13 siswa atau $61,90 \%$, kemudiannilai rata-rata kelas yang diperoleh adalah 67,61. Setelah pelaksanaan tindakan siklus I jumlah siswa yang tuntas meningkat menjadi 14 siswa atau 71,40\%, sedangkan 6 siswa masih belum tuntas atau $28,6 \%$, tetapi nilai rata-rata kelas meningkat menjadi 75 .Selanjutnya pada pembelajaran IPA siklus II semua siswa telah memperoleh nilai lebih dari KKM 71 dengan persentase $100 \%$, dan nilai rata-rata kelas siklus II meningkat menjadi 85. Dari data hasil belajar IPA dan ketuntasan belajar siswa siklus II tersebut dapat diketahui bahwa indikator keberhasilan tindakan penelitian menggunakan model pembelajaran interaktifyang telah ditentukan oleh peneliti sudah tercapai yaitu ketuntasan belajar siswa $\geq 85 \%$.

\section{Pembahasan}

Rendahnya aktivitas belajar IPA diketahui berdasarkan hasil observasi pembelajaran IPA prasiklus pada pokok bahasan struktur bumi di kelas 5 SD Negeri Lanjan 02. Hasil aktivitas guru prasiklus yang memperoleh total skor 45 dengan persentase sebesar $45 \%$, kemudian aktivitas individu siswa pada prasiklus yang memperoleh skor rata-rata 24,28 dengan persentase sebesar $60,71 \%$, ternyata dapat berpengaruh terhadap hasil belajar IPA pada pokok bahasan struktur bumi di kelas 5 SD Negeri Lanjan 02 yang dibuktikan berdasarkan tingkat ketuntasan hasil belajar prasiklus, bahwa siswa yang tuntas atau telah mencapai KKM (71) hanya 8 siswa dengan persentase sebesar $38,10 \%$, sedangkan siswa yang belum tuntas atau belum mencapai KKM sebanyak 13 siswa dengan persentase sebesar $61,90 \%$. Berdasarkan data tersebut maka perlu dilakukan tindakan perbaikan proses pembelajaran dengan meningkatkan aktivitas belajaragar hasil belajar IPA siswa kelas 5 SDN Lanjan 02 dapat meningkat melalui penerapan model pembelajaran Interaktif.

Setelah pembelajaran IPA dengan menerapkan model pembelajaran interaktif meliputi langkah pembelajaran kegiatan pengantar, aktivitas penyelesaian masalah, saling berbagi dan diskusi, meringkas, serta menilai belajar dan refleksi dilaksanakan secara keseluruhan pada siklus I dan siklus II. Ternyata siswa lebih berpartisipasi aktif dan interaktif dalam proses pembelajaran. Terbukti dari data hasil observasi aktivitas individu dan kelompok siswa yang telah dipaparkan pada tabel 2 dan tabel 3 di atas.

Meningkatnya aktivitas belajar diikuti dengan peningkatan hasil belajar IPA yang terlihat dari peningkatan nilai rata-rata kelas siklus 1 sebesar 75 dengan pencapaian ketuntasan belajar mencapai $71,40 \%$ masuk kriteria tinggi. Namun, pencapaian tersebut belum mencapai indikator keberhasilan yang telah ditentukan peneliti yaitu sebesar $85 \%$ ketuntasan klasikal, oleh karena itu diadakan refleksi sebagai perbaikan pada siklus II.Pada siklus II diperoleh nilai rata-rata kelas meningkat menjadi 85 dengan pencapaian ketuntasan belajar mencapai $100 \%$ tuntas dengan kriteria sangat tinggi. Berdasarkan hasil pencapaian ketuntasan pada siklus II,maka hasil pelaksanaan tindakan pada siklus II telah mencapai indikator ketuntasan yang ditetapkan peneliti sebesar $85 \%$ siswa tuntas. 
Keberhasilan peningkatan aktivitas dan hasil belajar IPA pada pokok bahasan daur air dan penghematan air, terjadi karena penerapan langkah-langkah atau sintaks model pembelajaran interaktif. Dalam proses pembelajaran guru bertindak sebagai fasilitator yang membimbing, mengawasi, mengarahkan dan mengkoordinasi kegiatan dan aktivitas siswa sehingga siswa lebih aktif dan dapat berpikir secara matematik dalam pemecahan masalah. Siswa belajar berdasarkan rasa keingintahuanya masing-masing kemudian mencari sendiri jawaban dan informasi dengan bimbingan guru lalu berdiskusi dan saling berbagi tentang hasil temuan yang mereka dapat dengan guru dan siswa lain. Kegiatan itu membuat siswa benar-benar memahami apa yang telah dipelajarinya dan membuat suasana pembelajaran menjadi interaktif dan menyenangkan. Sehingga dapat meningkatkan hasil belajar IPA pada pokok bahasan daur air dan penghematan air.

Berdasarkan uraian penelitian yang telah dipaparkan, maka penerapan model pembelajaran Interaktif dalam pembelajaran Ilmu Pengetahuan Alam (IPA) di kelas 5 Semester II SDN Lanjan 02 Tahun Pelajaran 2015/2016 ini selaras dengan penelitian sebelumnya oleh penelitian yang dilakukan oleh Dwi Agung Susanto (2012) dengan menerapkan model pembelajaran Interaktif mencapai ketuntasan 81\%, penelitian Bayu Widiyanto(2011) dengan menerapkan model pembelajaran Interaktif dengan media miniatur mencapai ketuntasan 86,66\%, dan Pasri (2012) dengan menerapkan model pembelajaran Interaktif mencapai ketuntasan $90 \%$. Sedangkan dalam penelitian ini ketuntasan belajar mencapai $100 \%$. Dari hasil penelitian tersebut terbukti bahwa penerapan model pembelajaran Interaktif dapat meningkatkan aktivitas belajardan hasil belajar.

Persamaan dengan penelitian sebelumnya sama-sama menggunakan model pembelajaran interaktif dan hasilnya terbukti mampu meningkatkan hasil belajar pada siswa. Namun, dalam penelitian ini terdapat perbedaan yaitu dalam meningkatkan hasil belajar lebih memfokuskan pada perbaikan proses belajar dengan miningkatkan aktivitas belajar yang meliputi aktivitas guru, aktivitas individu siswa, dan aktivitas kelompok siswa. Dalam upaya meningkatkan aktivitas belajar dilakukan dengan menerapkan langkah-langkah atau sintak model pembelajaran interaktif menurut pendapat Emma Holmes (dalam Irsyadi, 2011) yang meliputi 5 tahap, yaitu fase pengantar (introduction), Aktivitas atau pemecahan masalah (Activity/problem solving), Fase saling membagi dan diskusi (sharing and discusing), fase meringkas (summaring), dan penialaian unit belajar materi (assesment of learning of unit material).

Dalam penelitian ini sintaks model pembelajaran interaktif ditambahkan modifikasi kegiatan atau aktivitas seperti yang diuraikan dalam tabel 1. Modifikasi tersebut ditambahkan pada tahap pengantar dengan memberikan keleluasaan kepada siswa tentang bagaimana cara siswa belajar, yaitu belajar secara individu atau kerja kelompok. Dengan memberikan keleluasaan kepada siswa dalam melilih cara belajarnya siswa dapat merasa nyaman dan senang mengikuti pembelajaran. Kemudian pada tahap aktivitas penyelesaian masalah dimodifikasi dengan memberi siswa keleluasaan cara memecahkan masalahnya. Dengan modifikasi tersebut siswa dapat memungkinkan siswa melakukan berbagai kegiatan atau aktivitas dalam pembelajaran, diantaranya melakukan penyelidikan, percobaan, pengamatan, berdiskusi, permainan, atau membuat proyek dengan menyesuaikan materi pembelajaran. Modifikasi dalam kegiatan atau aktivitas tersebut dapat membantu guru dalam upaya menarik minat siswa mengikuti pembelajaran karena siswa diberikan keleluasaan dalam belajar. Selain itu guru lebih dimudahkan dalam memberikan pembelajaran karena siswa sendiri yang aktif menggali informasi, guru hanya memfasilitasi siswa, memberikan bimbingan dan arahan.

Berdasarkan paparan di atas, maka penelitian ini telah memberikan kontribusi ilmu yaitu model pembelajaran interaktif dengan sintak menurut Emma Holmes yang terdiri dari 5 sintak yang diberi modifikasi dalam kegiatan atau aktivitas pembelajaran yang lebih berorientasi pada siswa. Kontribusi ilmu pada sintak pertama yaitu siswa diberi keleluasaan untuk menentukan cara mereka belajar, secara individu atau kerja kelompok. Kemudian pada sintak ke dua aktivitas penyelesaian masalah, siswa dimungkinkan untuk dapat melakukan berbagai kegiatan atau aktivitas dalam pembelajaran, diantaranya penyelidikan, percobaan, pengamatan, diskusi, dan membuat proyek dengan menyesuaikan materi pembelajaran.

Mengacu pada penjelasan di atas dapat dipaparkan implikasi teoritis bahwa dengan penggunaan model pembelajaran interaktif, penelitian ini telah memberikan gambaran bagaimana penerapanya dalam pembelajaran IPA,sehingga dapat meningkatkan aktivitas dan hasil belajar. Selain itu kegiatan pembelajaran sudah disesuaikan dengan EEK (Eksplorasi, Elaborasi, dan Konfirmasi) dan menambahkan modifikasi dalam sintak pembelajarannya, maka telah mengalami perubahan dari teori 
Penerapan Model Pembelajaran Interaktif untuk Meningkatkan Aktivitas dan Hasil Belajar IPA Siswa Kelas 5 SD (Nugroho Widiantono, Nyoto Harjono)

aslinya. Sedangkan implementasi praktis, ternyata melalui penerapan model pembelajaran interaktif dalam pembelajaran IPA, siswa lebih aktif dan berani mengungkapkan rasa ingin tahunya melalui pertanyaan dan berpendapat, sehingga dapat meningkatkan aktivitas dan hasil belajar. Selain itu, guru dapat menciptakan suasana interaktif dalam pembelajaran IPAmenggunakan model pembelajaran interaktif. Model pembelajaran interaktif dapat menjadi alternatif pilihan untuk mengatasi permasalahan siswa yang pasif. Berdasarkan pembahasan tersebut, maka tujuan penelitian telah tercapai bahwa penerapan model pembelajaran interaktif dalam pembelajaran IPA pada siswa kelas 5 SDN Lanjan 02 dapat meningkatkan aktivitas dan hasil belajar IPA khususnya K.D 7.4 dan K.D 7.5.

\section{PENUTUP}

\section{Simpulan dan Saran}

Setelah menerapkan model pembelajaran interaktif dengan langkah-langkah meliputi tahap pengantar, tahap aktivitas penyelesaian masalah, tahap saling berbagi dan diskusi, tahap meringkas, dan tahap menilai belajar pada mata pelajaran IPA.Dapat dianalisis kesimpulan bahwa penerapan model pembelajaran interaktif dapat meningkatkan aktivitas belajar dan hasil belajar IPA siswa kelas 5 SDN Lanjan 02 semester II tahun pelajaran 2015/2016 pada pokok bahasan daur air dan penghematan air. Berdasarkan hasil penelitian yang telah dipaparkan, aktivitas belajar yang meliputi aktivitas guru, aktivitas individu siswa, dan aktivitas kelompok siswa dari prasiklus mengalami peningkatan setelah diterapkannya model pembelajaran interaktif pada siklus I dan siklus II.Demikian dengan hasil belajar IPA yang meliputi nilai rata-rata kelas dan ketuntasan belajarklasikal mengalami peningkatan.

\section{Ucapan terimakasih}

Dengan ini penulis mengucapkan terimakasih kepada SD Negeri Lanjan 02 Kecamatan Sumowono Kabupaten Semarang yang telah memberikan ijin pelaksanaan penelitian tindakan kelas di kelas 5.Selanjutnya, terimakasih kepada Prof. Dr. Slameto, M.Pd. yang telah melakukan review terhadap artikel ilmiah ini.

\section{DAFTAR PUSTAKA}

Arikunto, S. (2010). Prosedur Penelitian: Suatu Pendekatan Praktik(Revisi 2010). Yogyakarta: Rineka Cipta.

S., Suhardjono, \& Supardi. (2012). Penelitian Tindakan Kelas (Revisi). Jakarta: Bumi Aksara.

Dasna, I. W. (2015). Modul: Desain dan Model Pembelajaran Inovatif dan Interaktif. Universitas Terbuka. (online). (https://repository.ut.ac.id/4324/1/MPDR5203-M1.pdf), diakses 22 April 2016.

Djaali, \& Muljono, P. (2008). Pengukuran Dalam Bidang Pendidikan. Jakarta: Grasindo.

Hanafiah, N., \& Suhana, C. (2010). Konsep Srategi Pembelajaran. Bandung: Refika Aditama.

Irsyadi, M. K. (2011). Peningkatan Hasil Belajar Operasi Hitung Bilangan Bulat Melalui Model Pembelajaran Interaktif.Jurnal CAKRAWALA PENDIDIKAN: STKIP PGRI Blitar. 13 (2): 281-293.

Majid, A. (2014). Strategi Pembelajaran. Bandung: Remaja Rosdakarya.

Pasri. (2012). Upaya Peningkatan Hasil Belajar Siswa Tentang Penggolongan Hewan Berdasarkan Makanannya Melalui Model Pembelajaran Interaktif di Kelas IV SD Karangwotan 03 Semester 1 Tahun 2011/2012.Skripsi tidak diterbitkan. Salatiga: Universitas Kristen Satya Wacana.

Prayekti. (2004). Penerapam Model Pembelajaran Interaktif Pada Mata Pelajaran IPA di SD. Jurnal Teknologi Pendidikan. (online), (http://www.teknologipendidikan.net), diakses 20 April 2016. 
Scholaria: Jurnal Pendidikan dan Kebudayaan, Vol 7 No 3, September 2017: 199 - 213

Rusman. (2010). Model-model Pembelajaran: Mengembangkan Profesionalisme Guru. Jakarta: Rajawali Press.

Rusmana, N. (2007). Konsep dasar Dinamika Kelompok. (online),

(http://file.upi/Direktori/FIP/JUR_PSIKOLOGI_PEND_DAN_BIMBINGAN/196005011986

031-NANDANG_RUSMANA/Konsep_Dasar_Dinamika_Kelompok.pdf), diakses 28 April 2016.

Samatowa, U. (2006). Bagaimana Membelajarkan IPA di Sekolah Dasar. Jakarta: Direktorat Pendidikan Nasional.

Santosa, S. (2004). Dinamika KelompokEdisi Revisi Cetakan ke 1. Jakarta: Bumi Aksara.

Sardiman, A. M. (2011). Interaksi dan Motivasi Belajar Mengajar. Jakarta: Rajawali.

Slameto. (2015). Metodologi Penelitian dan Inovasi Pendidikan. Salatiga: Satya Wacana University Press.

Sudjana, N. (2012). Penilaian Hasil Proses Belajar Mengajar. Bandung: Remaja Rosdakarya.

Sugiyono. (2013). Metode Penelitian Kuantitatif, Kualitatif dan R\&D (Cetakan 19). Bandung: Alfabeta.

Sulistyorini, S. (2007). Pembelajaran IPA Sekolah Dasar. Yogyakarta: Tiara Wacana.

Susanto, D. A. (2012). Peningkatan Motivasi Belajar IPA Melalui Model Pembelajaran Interaktif Pada Siswa Kelas IV Semester I SD Wotan 02 Sukolilo Pati Tahun Pelajaran 2012/2013.Skripsi tidak diterbitkan.Surakarta: Universitas Muhammadiyah Surakarta.

Widiyanto, B. (2011). Penerapan Model Pembelajaran Interaktif Dengan Media Miniatur Untuk Meningkatkan Hasil Belajar IPA Pada Siswa Kelas III SDN Kemuning Lor 02 Jember.Skripsi tidak diterbitkan. Jember: Universitas Jember

Widodo, A. (2007). Pendidikan IPA di SD (BBM). Bandung: UPI. (online), (https:/file.ipi.edu/Direktori/DUAL_MODES/PENDIDIKAN_IPA_DI_SD/BBM_6.pdf), diakses tanggal 14 Januari 2016.

\section{Profil Singkat}

Penulis 1

Nugroho Widiantono adalah mahasiswa Program Studi Pendidikan Guru Sekolah Dasar, Fakultas Keguruan dan Ilmu Pendidikan Universitas Kristen Satya Wacana sejak tahun 2012 dan sedang menempuh Tugas Akhir untuk memperoleh gelar Sarjana.

Penulis 2

Nyoto Harjono adalah staf pengajar pada Program Studi Pendidikan Guru Sekolah Dasar, Fakultas Keguruan dan Ilmu Pendidikan Universitas Kristen Satya Wacana sejak tahun 2006 sampai sekarang. Beberapa karya yang telah ditulis antara lain: Bahasa Indonesia untuk SD/MI kelas 4, 5, dan 6 (PT Pabelan Cerdas Nusantara, 2007); Pembelajaran Bahasa Indonesia SD (Widya Sari, 2009); Kajian Bahasa Indonesia (Widya Sari, 2009); "Kajian Stilistika Puisi-puisi Chairil Anwar sebagai Sarana Pembelajaran Apresiasi Sastra" (Jurnal Scholaria, 2012); Analisis Kesalahan-kesalahan Dalam Menulis Paragraf (Jurnal Scholaria, 2012); Evaluasi Pembelajaran Siswa Aktif pada Mata Pelajaran Bahasa Indonesia (Jurnal Seloka, 2012). 